\title{
Characterizations of Colloidal Organic Matter Isolated from Surface Water
}

Boksoon $\mathrm{Kwon}^{1}$, Jaeweon $\mathrm{Cho}^{1 *}$

${ }^{1}$ NOM ecology National Research Laboratory, Department of Environmental Science and Engineering, Gwangju Institute of Science and Technology (GIST), 1 Oryong-dong, Buk-gu, Gwangju 500-712, Korea

*Corresponding author: Tel. 82-62-970-2443, e-mail: jwcho@gist.ac.kr

\section{Abstract}

This study investigated the effect of the molecular weight cut-off (MWCO) of a dialysis membrane for the isolation of colloidal organic matter (COM) from surface water. Various dialysis membranes with different MWCO were used for the isolation of COM from Cebron reservoir natural organic matter (CRNOM). The COM included mainly amino sugars (30 40\%) and polysaccharides (30 40\%), with 2 3 of fatty acids over aromatic acids (F/A ratio), indicating that the COM were derived from microbial substances. As all the COM constituents were found to have similar characteristics, the MWCO of the dialysis membrane was not found to influence the COM characteristics.

Keywords: Colloidal organic matter, dialysis membrane, natural organic matter, organic characterization 


\section{Introduction}

Colloidal organic matter (COM) is defined solely on the basis of size, and typically ranges from 0.45 $\mu \mathrm{m}$ to $1 \mathrm{~nm}$ in diameter [1]. COM accounts for less than 10 percent of the organic carbon for most natural waters [1], but they are abundant in natural seawater, ranging from $20-40 \%$ in coastal waters to $60-70 \%$ in estuarine waters [2]. COM in ground water might greatly enhance the transport of chemical contaminants and have a major influence on the fate of contaminants by the association of contaminants with colloids [3]. Furthermore, colloidal-sized macromolecular organic matter can strongly bind with certain trace metals and organics to from organic complexes. Consequently, the biological availability of trace metals for the metabolism of aquatic organisms is hindered [4]. In marsh and swamps waters, the COM is peptized by waters with a low ionic strength (i.e., specific conductance $<50 \mu \mathrm{S}$ ), but can aggregate and precipitate out if the salt content of the water increases [1]. Several biological (i.e., bacterial respiration) and physical processes (i.e., aggregation of microfibrils) contribute to the production of marine colloids [5]. The phytoplankton exopolymers (mainly microfibrils of polysaccharides) are considered one of the most direct physical means of COM production [6]. However, bacterial respiration is the major biological process regulating the net production of COM in aquatic ecosystems [7-8]. Therefore, the variation of COM concentration and composition in water is governed by the interaction between biological and physical factors that are influenced by specified ecological conditions. This COM fraction could be described as missing NOM 
possessing hydrophilic (polar) base/neutral characteristics [9], which are non humic substances derived from algae and bacteria [10].

Recently, a dialysis membrane with a molecular weight cut off (MWCO) of $3.5 \mathrm{kDa}$ [11] was used to recover the colloidal NOM fraction often lost using the sorbent resin isolation method [12]. Leenheer et al. [11] analysed drinking water from USA and found that colloidal fraction of natural organic matter (NOM) is composed of polar amino sugars when isolated using a dialysis membrane bag with a MWCO of $3.5 \mathrm{kDa}$. On the other hand, IR spectra and pyrolysis GC-MS analysis of COM isolated using a dialysis membrane bag with MWCO of 12-14 kDa exhibited the presence of polysaccharides, amino sugars and protein in drinking water from Korea [13]. Despite water composition variation, the use of dialysis membrane bags with different MWCO has a great influence on the COM composition of tested waters.

Many studies were reported on measuring the composition and the particle size distribution of organic matter in water $[8,14-16]$. Dissolved organic carbon can be analyzed by high-pressure size exclusion chromatograph (HPSEC), gel filtration, flow field flow fractionation (FlFFF) and ultrafiltration techniques [16]. The analysis of size and molecular weight (MW) of humic samples using HPSEC by Chin and Gschwend [17] exhibited similar results to those reported by Schimpf and Petteys [18] for FIFFF. Moreover, Assemi et al. [14] concluded that the molecular weight distribution (MWD) obtained from both FIFFF and HPSEC was quite similar when characterizing the MWD of natural 
organic matter fractions obtained by a series of commonly used UF membranes. FlFFF has been extensively used for the size fractionation of fresh waters [14, 19-20]; it is considered a convenient method because it does not require chromatography packing material and covers the size range from $500 \mathrm{Da}$ to $1 \mu \mathrm{m}$ [15]. The use of FIFFF with the "on channel pre-concentration" method was successful for the determination of UV absorbing chromophoric colloid organic matter in seawater and brackish water [15].

The objectives of this study were i) to isolate COM using a dialysis bas with different MWCO, ii) to investigate the effect of COM separation with different MWCO and iii) to characterize detailed COM compound and size in terms of HPSEC, FFFF, pyrolysis-GC/MS, tetra methyl ammonium hydroxidethermochemolysis-GC/MS and Fourier transform infrared (FTIR) spectra.

\section{Materials and methods}

\section{Colloidal organic matter (COM) isolation}

The isolation of COM was conducted with Cebron reservoir NOM (CRNOM), France using Spectra/Por regenerated cellulose dialysis membranes with different MWCO (2, 3.5, 12-14, 25 and 50 $\mathrm{kDa}$ ). The water sample was concentrated (approximately $100 \mathrm{mg} / \mathrm{L}$ as dissolved organic carbon (DOC)) using a vacuum rotary evaporator followed by a spiral-wound reverse osmosis membrane with 100 Da MWCO (polyamide, Saehan, Korea). Then, it was filtered through a $0.45 \mu \mathrm{m}$ membrane. The 
sample was acidified to $\mathrm{pH} 1$ with a concentrated $\mathrm{HCl}$ solution. A total of $100 \mathrm{~mL}$ of each sample was poured into a cleaned dialysis bag with the bottom side stopped using a plastic snap closure. After pouring the water sample, the top of the bag was closed with another closure. The dialysis bag was placed in an acrylic beaker filled with $4 \mathrm{~L}$ of $0.1 \mathrm{~N} \mathrm{HCl}$. Dialysis was then conducted with stirring using a magnetic stirrer. During the dialysis the low molecular weight NOM and salts contained in the sample were dialyzed against $0.1 \mathrm{~N} \mathrm{HCl}$. Soon after, the dialysis bag was placed in $4 \mathrm{~L}$ of $0.2 \mathrm{~N}$ hydrofluoric (HF) acid solution until all the silica gel precipitates were dissolved. A final dialysis against $4 \mathrm{~L}$ of pure water was conducted to remove the residual HF from the dialysis bag. The retained NOM in the dialysis bag was referred to as colloidal organic matter. The experimental apparatus for the isolation of COM is described in Fig. 1.

High performance size exclusion chromatograph (HPSEC) and Flow-Field Flow Fractionation $($ F-FFF)

MWD of COM from the dialyzed NOM bag against the COM from external solutions was evaluated to better understand the effectiveness of COM isolation in relation to the MWCO of the dialysis membranes. The MWD was measured using a high performance liquid chromatograph (HPLC, NS2001P, Futects, Korea) equipped with UV detector (SPD-10A UV-VIS detector, Shimadzu, Japan) at $254 \mathrm{~nm}$ and a fluorescence (FL) detector (RF-10A XL, Shimadzu, Japan) at excitation and emission 
wavelengths of 278 and 353 nm, and a DOC detector (Modified Sievers Turbo Total Organic Carbon Analyzer, US). The FL detector was used at the selected wavelength to detect protein-like substances [21], while UV detector was adjusted to measure aromatic compounds from NOM. With the exception of carbon single bonds, the DOC analyzer virtually detected all the organic carbon in the NOM sample. The column used was a silica column (Protein pak 125, Waters, US). The mobile phase was prepared with $96 \mathrm{mM} \mathrm{NaCl}$ and phosphate buffer $\left(2.4 \mathrm{mM} \mathrm{NaH} \mathrm{PO}_{4}\right.$ and $\left.1.6 \mathrm{mM} \mathrm{Na} 2 \mathrm{HPO}_{4}\right)$ with a total ionic strength of $0.1 \mathrm{M}$ at a $\mathrm{pH}$ of 6.8. Sodium polystyrene sulfonates (PSS, 210, 1800, 4600, 8000 and $18000 \mathrm{~g} / \mathrm{mol}$ ) were used as standard solutions to determine the MW calibration curve. The MW range of the separation with the silica column used is $2000-80,000 \mathrm{~g} / \mathrm{mol}$. The COM probably contains the MW above 80,000 g/mol, which cannot be separated by the silica column. Therefore, a flow-field flow fractionation (FIFFF) technique capable of high-resolution separation of colloids and particles (1 nm $100 \mu \mathrm{m})$, was used to solve the limitation of HPSEC in measuring COM. The carrier solution for the FIFFF system consisted of $10 \mathrm{mM} \mathrm{KCl}$ and $10^{-4} \mathrm{M}$ sodium azide. The MW calibration standards consisted of nominal weights of 840, 1430, 4800 and $6500 \mathrm{~g} / \mathrm{mol}$ PSS. This FlFFF system was also connected with DOC, UV and FL detectors.

\section{Pyrolysis-GC/MS and TMAH thermochemolysis-GC/MS}

Pyrolysis Gas Chromatography/Mass Spectrometry (GC/MS) was used to characterize specific 
components of NOM [22]. Pyrolysis GC/MS provides molecular level information of NOM that yields specific fragments such as low MW thermal decomposition products. A freeze-dried COM powder was placed into $100 \mu \mathrm{L}$ quartz tubes, with both end sides filled with quartz wool. The quartz tube samples were inserted into the platinum filament of the pyrolysis probe and then heated to a final temperature of $625^{\circ} \mathrm{C}$, at a rate of $20^{\circ} \mathrm{C} / \mathrm{ms}$. After pyrolysis, the thermal degradation fragments were separated by a gas chromatograph equipped with a 30 m DB WAX fused silica capillary column, and identified using a mass spectrometer. Pyrolysis GC/MS is unable to characterize polar compounds and oxygenated NOM fractions well because pyrolysis causes the release of oxygenated functional groups, such as CO and $\mathrm{CO}_{2}$. However, the tetramethylammonium hydroxide (TMAH) thermochemolysis GC/MS technique avoids unwanted thermal decarboxylation and dehydroxylation, rendering the degradation products more amenable to GC/MS analysis due to methylation of the $\mathrm{OH}$ - and $\mathrm{COOH}$-groups, which make them more volatile. A total of $45 \mu \mathrm{L}$ of TMAH (50\% in methanol) was added to $5 \mathrm{mg}$ of COM powder. During the reaction, the TMAH-COM mixture was dried on an evaporator of $40^{\circ} \mathrm{C}$ for 24 hrs. The sample was pyrolyzed and then analyzed by GC/MS.

\section{Results and discussion}

\section{Molecular weight distribution (MWD) of COM isolated from CRNOM}

The MWD of COM isolated from the concentrated NOM from Cebron reservoir water was measured 
using HPSEC for different COM using dialysis membranes with different MWCOs. The MWCO of the dialysis membrane was expected to influence the separation of COM compositions with respect to size. Based on the DOC response of HPSEC, COM separated by different MWCO dialysis membranes was interestingly found to include the low MW NOM $(<1,000 \mathrm{~g} / \mathrm{mol})$ (Fig. 2 (a)). The MWD of COM was classified into three regions (i.e., I, II and III in Fig. 2 (a)). Only the dialysis membrane with a MWCO of 50 kDa preferentially separated low MW NOM. This can be concluded that only a dialysis membrane with a MWCO of more than $50 \mathrm{kDa}$ can effectively separate a low MW COM.

Fig. 2 (a) shows that the separation ability of each dialysis membrane with different MWCO. The MW portion detected by UV in the COM ranged from 1,000 to 10,000 g/mol (Fig. 2 (b)), which related to region II in the DOC response. This result indicates that the aromatic compounds of this MW range decreased with increasing MWCO.

Fig. 2 (c) illustrates that the protein like substances measured at the wavelengths (ex. $278 \mathrm{~nm}$ and em. $353 \mathrm{~nm}$ ) for FL had molecular masses between 1,000 and 40,000 g/mol. Herein, the phase of graph was very similar to regions II and III in the DOC response. The COM isolated by the $50 \mathrm{kDa}$ dialysis membrane contained somewhat higher MW NOM, ranging from 10,000 to 40,000 g/mol, compared to other COM.

Fig. 3 shows the fractograms of COM using FIFFF. The fractograms by the FIFFF measurment were much broader than chromatograms of HPSEC. The remarkable point in Fig. 3 (a) was that the peak 
point was shifted toward the higher MW range with increasing MWCO of the dialysis membrane. The MWD of COM via both UV (Fig. 3 (b)) and FL (Fig. 3 (c)) was the same as those for HPSEC, but the MW indicating peak points was slightly different between FIFFF and HPSEC.

\section{Pyrolysis-GC/MS and TMAH-thermochemolysis-GC/MS analyses of COM isolated from}

\section{CRNOM}

The peak areas of pyrochromatograms obtained in COM isolated from CNROM by pyrolysis GC/MS are presented in Table 1. These chromatograms are dominated by common pyrolysis fragments of the four main types of biopolymer such as polysaccharides, N-acetyl amino sugars and polyphenolic compounds (polyhydroxy aromatics), and proteins. The thermal decomposition of fragments corresponding to each biopolymer is summarized by Hwang et al. [23]. The acetic acid (carbohydrate moieties present in both polysaccharides and $N$-acetyl amino sugars) and acetamide peak areas (indicator of $\mathrm{N}$-acetyl amino sugars present in bacterial or fungal cell walls) were markedly exhibited in all COM (Table 1). The fragments for proteins such as acetonitrile, toluene, ethylbenzene, pyridine, and styrene and polyhydroxy aromatics such as phenol and para cresol were released in low amounts in COM. Pyrolysis-GC/MS released high amounts of oxygenated functional groups, such as carbon dioxide $\left(\mathrm{CO}_{2}\right)$, which resulted from the unwanted thermal decarboxylation and dehydroxylation of acidic functional groups such as $\mathrm{COOH}$ and $\mathrm{OH}$. 
The properties of the four main types of biopolymer in COM were calculated from the total peak areas of each biopolymer multiplied by the corrective factor obtained by Bruchet et al. [22], using a standard mixture of dextran, bovine serum albumin, cellulose acetate, humic acid and chitin, to account for the differences in sensitivity between the biopolymers (Table 2). The COM isolated from CRNOM consisted of high proportions (approx. 30 40\%) of polysaccharides and amino sugars biopolymers and low proportions (approx. 10 20\%) of proteins and polyhydroxy aromatics. Moreover, there was no clear tendency observed in semi-quantitative data obtained for the biopolymers of COM with increasing MWCO of the dialysis membrane.

Since hydroxylated or carboxylated compounds can be characterized using a TMAH thermochemolysis-GC/MS technique, it was used to characterize COM in terms of fatty acids (FA) and aromatic acids (Ar). The peak areas from the chromatograms are listed in Table 3, with the ratio of fatty acid and aromatic acids (F/A) calculated from their total peak areas. Some peaks indicating fatty acids and aromatic acids in chromatograms were identified. Carboxylic acids can be subdivided into fatty acids, hydroxy acids, dicarboxylic acids and aromatic acids. Fatty acids originate from algae, terrestrial plants and the microbiological degradation of both dissolved and particulate organic matter in aerobic and anaerobic environments. Hydroxy and dicarboxylic acids originate from plant degradation products and biochemical cycles. Aromatic acids are lignin degradation products, conjugated with the structure of humic substances [1]. The ratio of fatty acids/aromatic acids from 
TMAH GC/MS indicated 2.78, 2.07 and 3.11 for COM isolated using dialysis bags with MWCO of 3.5, 25, $50 \mathrm{kDa}$, respectively. Therefore, COM abundant constituents were usually derived from microbial inputs rather than from lignin-derived compounds.

\section{Fourier Transform IR (FTIR) spectrometry of COM isolated from CRNOM}

The FTIR spectra of COM isolated using dialysis bags with MWCO of 3.5 and $50 \mathrm{kDa}$ were measured (Fig. 4). This identification of peaks was done based on the information reported by Barrett et al. [24]. The broad $\mathrm{OH}$ peak at 3,400 3,300 $\mathrm{cm}^{-1}$ and C-O peak at 1,100 1,000 $\mathrm{cm}^{-1}$ for carbohydrates, the amide $1\left(1660 \mathrm{~cm}^{-1} ; \mathrm{N}-\mathrm{C}=\mathrm{O}\right)$ and amide $2\left(1550 \mathrm{~cm}^{-1} ; \mathrm{N}=\mathrm{C}-\mathrm{O}\right)$ peaks (presumed as indicators of bacterial cell fragments) and the methyl peak $\left(\mathrm{CH}_{3}\right)$ at $1380 \mathrm{~cm}^{-1}$ were found in the isolated COM fraction. A marked difference between the COM with the silica removed by HF solution and those with residual silica in the absence of the HF dialysis procedure was shown via the broad band from 900 to $400 \mathrm{~cm}^{-1}$, which was due to $\mathrm{N}-\mathrm{H}$ bending vibrations of the secondary amides of the N-acetyl group in amino sugars. This band was suppressed in the presence of silica, which may be an indication of hydrogen-bonding interactions of the $\mathrm{N}-\mathrm{H}$ of the amides with the silica in the sample.

\section{Concluding remarks}

COM isolated by the dialysis membranes with different MWCO showed similar characteristics in 
terms of MWD, pyrolysis-GC/MS, TMAH-thermochemolysis-GC/MS and FTIR spectra. The MWD of COM from FIFFF was the same as that from HPSEC, but the MW indicating peak points were slightly different. Different MWCO dialysis bag did not show any variation in the collected COM, consequently the MWCO of the dialysis membrane for isolating colloidal based on size cut-off was not very accurate. But if COM with low MW NOM was collected, a relatively higher MWCO (50 $\mathrm{kDa}$ ) dialysis membrane can be utilized.

High proportions (approx. 30 40\%) of polysaccharides and amino sugars biopolymers and low proportions (approx. 10 20\%) of proteins and polyhydroxy aromatics were identified in COM from CNROM. Based on TMAH GC/MS analysis, COM from CNROM was derived form microbial inputs rather than from lignin-derived compounds. This was confirmed by FTIR where most of COM was found to be derived from algae and microbial degradation.

\section{Acknowledgements}

This research was supported by a grant from the National Research Laboratory Program by the Korea Science and Engineering Foundation (NOM ecology Lab: R0A-2007-000-20055-0), and also partially supported by Université de Poitiers, Lab. Chimie de I'Eau et de I'Environnement, UMR CNRS6008.

\section{References}


1. Thurman, E.M. (1985) Organic geochemistry of natural waters; Kluwer academic publishers:

Dordrecht, Boston, Lancaster.

2. Guo, L.D. and Santschi, P.H. (1997) Composition and cycling of colloids in marine environment. Reviews of Geophys. 35 (1), p. 17.

3. Shafer, M.M., Dean, K.E. and Armstrong, D.E. (1991) Role of mobile colloids in the transport of chemical contaminants in groundwaters; Final report to USGS and University of Wisconsin Water Resources Center: USA.

4. Wang, W.-X. and Guo, L. (2000) Influence of natural colloids on metal bioavailability to two marine Bivalves. Environ. Sci. Technol. 34 (21), p. 4571.

5. Niven, S.E.H., Kepkay, P.E. and Boraie, A. (1995) Colloidal organic carbon and colloidal 234Th dynamics during a coastal phytoplankton bloom. Deep-Sea Res. II 42, p. 257.

6. Hoagland, K.D., Rosowski, J.R., Gretz, M.R. and Roemer, S.C. (1993) Diatom extracellular polymeric substances: Function, fine structure, chemistry and physiology. J. Phycol. 29, p. 537.

7. Kepkay, P.E., Niven, S.E.H. and Milligan, T.G. (1993) Low molecular weight and colloidal DOC production during a phytoplankton bloom. Mar. Ecol-Prog. Ser. 100 (3), p. 233.

8. Seredynska-Sobecka, B., Baker, A. and Lead, J.R. (2007) Characterisation of colloidal and particulate organic carbon in freshwaters by thermal fluorescence quenching. Water Res. 41, p. 3069. 9. Croué, J.-P., Korshin, G.V. and Benjamin, M. (2000) Characterization of natural organic matter in 
drinking water; AwwaRF and AWWA: Denver, Colo.

10. Croué, J.-P., Debroux, J.-F., Amy, G.L., Aiken, GR. and Leenheer, J.A. (1999) Natural organic matter, structural characteristics and reactive properties. In: Formation and control of disinfection byproducts in drinking water; Singer P.C.(Ed), AWWA: Denver, Colo.

11. Leenheer, J.A., Croue, J.-P., Benjamin, M., Korshin, G.V., Hwang, C.J., Bruchet, A. and Aiken, G.R. (2000) Comprehensive isolation of natural organic matter from water for spectral characterizations and reactivity testing. In: ACS symposium series, natural organic matter and disinfection by-products, characterization and control in drinking water; American Chemical Society: Washington DC, USA.

12. Aiken, G.R., Thurman, E.M., Malcolm, R.L. and Walton, H.F. (1979) Comparison of XAD macroporous resins for the concentration of fulvic acid from aqueous solution. Analyt. Chem. 51, p. 1979.

13. Park, N., Kwon, B., Kim S.-D. and Cho, J. (2006) Characterizations of the colloidal and microbial organic matters with respect to membrane foulants. J. Membrane Sci. 275, p. 29.

14. Assemi, S., Newcombe, G., Hepplewhite C. and Beckett, R. (2004) Characterization of natural organic matter fractions separated by ultrafiltration using flow field-flow fractionation. Water Res. 38, p. 1467. 
15. Hassellov, M. (2005) Relative molar mass distributions of chromophoric colloidal organic matter in coastal seawater determined by Flow Field-Flow Fractionation with UV absorbance and fluorescence detection. Mar. chem. 94, p. 111.

16. Shon, H.K., Kim, S.-H., Erdei, L. and Vigneswaran, S. (2006) Analytical methods of size distribution for organic matter in water and wastewater. Korean J. Chem. Eng. 23(4), p. 581.

17. Chin, Y.P. and Gschwend, P.M. (1991) The abundance, distribution, and configuration of porewater organic colloids in recent sediments. Geochim Cosmochim Acta 55, p. 1309.

18. Schimpf, M.E. and Petteys, M.P. (1997) Characterization of humic materials by flow field-flow fractionation. Colloids Surf. A, 120(1-3), p. 87.

19. Lyvén, B., Hassellov, M., Turner, D.R., Haraldsson, C. and Andersson, K. (2003) Competition between iron- and carbon-based carriers for trace metals in a freshwater assessed using flow field-flow fractionation coupled to ICPMS. Geochim. Cosmochim. Ac. 67 (20), p. 3791.

20. Thang, N.M., Geckeis, H., Kim, J.I. and Beck, H.P. (2001) Application of the flow field flow fractionation (FFFF) to the characterization of aquatic humic colloids: evaluation and optimization of the method. Colloid. Surface. A 181, p. 289.

21. Her, N., Amy, G., Park, H.-R. and Song, M. (2004) Characterizing algogenic organic matter (AOM) and evaluating associated NF membrane fouling. Wat. Res. 38 (2004), p. 1427.

22. Bruchet, A., Rousseau, C. and Mallevialle, J. (1990) Pyrolysis-GC-MS for investigating high- 
molecular-weight THM precursors and other refractory organics. Journal. AWWA 82 (9), p. 66.

23. Hwang, C.J., Krasner, S.W., Amy, G.L., Dickenson, E., Bruchet, A., Prompsy, C., Filippi, G., Croué, J.-P., Violleau, D. and Leenheer, J.A. (2000) Polar NOM: characterization, DBPs, treatment; AwwaRF and AWWA: Denver, Colo.

24. Barrett, S.E., Krasner, S.W. and Amy, GL. (2000) Natural organic matter and disinfection byproducts characterization and control in drinking water: ACS symposium series 761, p. 68-83. 
Table 1. Pyrolysis GC/MS peak areas of the common fragments for COM from CRNOM isolated using dialysis bags with different MWCO (3.5, 12-14, 25, and $50 \mathrm{kDa})$

Table 2. Overall semi-quantitative estimation of biopolymers (\%) in COM without miscellaneous and $\mathrm{CO}_{2}$ peaks.

Table 3. Peak identification of TMAH thermochemolysis-GC/MS products of the COM from CRNOM isolated using dialysis bags with different $\operatorname{MWCO}(3.5,25$, and $50 \mathrm{kDa})$ 
Table 1. Pyrolysis GC/MS peak areas of the common fragments for COM from CRNOM isolated using dialysis bags with different MWCO (3.5, 12-14, 25, and $50 \mathrm{kDa})$

\begin{tabular}{|c|c|c|c|c|c|}
\hline \multirow{2}{*}{ Pyrolysis fragment } & \multirow{2}{*}{$\begin{array}{l}\text { Biopolymer } \\
\text { Type }\end{array}$} & \multicolumn{4}{|c|}{ Sample area $\left(\mathrm{x} 10^{5}\right)$} \\
\hline & & $3.5 \mathrm{kDa}$ & $12-14 \mathrm{kDa}$ & $25 \mathrm{kDa}$ & $50 \mathrm{kDa}$ \\
\hline $\mathrm{CO}_{2}$ & & 301 & 57.2 & 303.4 & 301.8 \\
\hline Methanethiol & & 22.6 & 40.4 & 21.9 & 22.4 \\
\hline Acetaldehyde & & 50.5 & 120.1 & 53.6 & 66.7 \\
\hline 1,3-Cyclopentadiene & & 14.6 & 41.5 & 13.9 & 21.4 \\
\hline Furan & & 20.5 & 56.0 & 18.5 & 19.9 \\
\hline Acetone & & 42.3 & 76.8 & 36.0 & 37.2 \\
\hline 2-Propenal & & 8.3 & 37.4 & 6.9 & 5.5 \\
\hline Furan, 2-methyl- (Methyl Furan) & $\mathrm{PS}^{*}$ & 21.3 & 51.0 & 21.0 & 19.8 \\
\hline 2-Butanone & & 7.4 & 14.0 & & 12.7 \\
\hline Benzene & $\mathrm{PHA}^{* *}$ & 20.7 & 62.2 & 14.7 & 24.5 \\
\hline 2-Propenenitrile & & 12.0 & 43.0 & 10.3 & 15.3 \\
\hline Acetonitrile & $\mathrm{PR}^{* * *}, \mathrm{AS}^{* * * *}$ & 88.0 & 223.7 & 77.5 & 99.2 \\
\hline Toluene & PR & 63.4 & 145.8 & 61.1 & 73.7 \\
\hline Ethylbenzene & & 17.6 & 41.7 & 16.1 & 20.8 \\
\hline Pyridine & PR & 14.8 & 37.9 & 11.4 & 15.7 \\
\hline Pyridine, 2-methyl- (Methyl pyridine) & PR & 7.1 & 20.1 & 5.2 & 6.8 \\
\hline Styrene & PR & 10.0 & 33.8 & 9.6 & 13.8 \\
\hline 2-Cyclopenpenten-1-one & & 9.6 & 5.2 & 8.0 & 10.0 \\
\hline Acetic acid & PS, AS & 302.9 & 564.3 & 27.2 & 286.9 \\
\hline 2-Furancarboxyaldehyde(Furfural) & PS & 31.3 & 38.4 & 22.7 & 19.2 \\
\hline Formic acid & & 22.1 & 92.3 & 29.5 & 14.8 \\
\hline Pyrrole & PR & 32.8 & 93.2 & & 38.8 \\
\hline 1H-Pyrrole, 3-methyl- & & 11.4 & 29.2 & 10.4 & 12.3 \\
\hline $\begin{array}{l}\text { 2-Furancarbo xyaldehyde, 5-methyl-(Methyl } \\
\text { Furfural) }\end{array}$ & PS & 25.4 & 36.3 & 20.3 & 15.2 \\
\hline Acetamide & AS & 152.8 & 352.8 & 149.3 & 157.6 \\
\hline Phenol & PHA, PR & 29.3 & 78.6 & 23.3 & 25.9 \\
\hline 2-Pyrrolidinone & & 5.9 & 21.8 & & \\
\hline Phenol, 4-methyl- (Para cresol) & PR, PHA & 18.9 & 49.7 & 21.6 & 18.0 \\
\hline
\end{tabular}

*PS: polysaccharide, ${ }^{* *}$ PHA: polyhydroxyaromatic (polyphenolics), ${ }^{* * *}$ PR: protein, ${ }^{* * * *}$ AS, amino sugars 
Table 2. Overall semi-quantitative estimation of biopolymers (\%) in COM without miscellaneous and $\mathrm{CO}_{2}$ peaks.

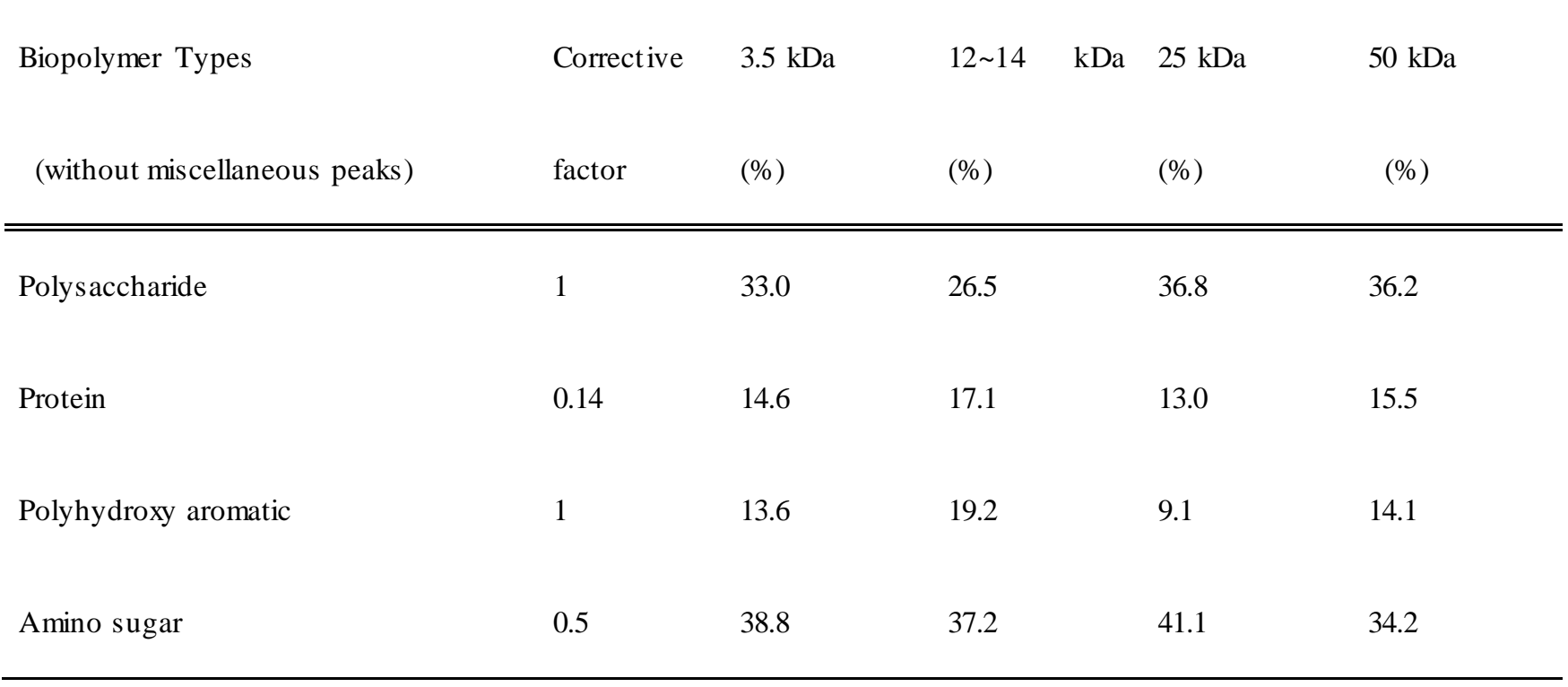


Table 3. Peak identification of TMAH thermochemolysis-GC/MS products of the COM from CRNOM isolated using dialysis bags with different $\operatorname{MWCO}(3.5,25$, and $50 \mathrm{kDa})$

\begin{tabular}{|c|c|c|c|c|c|c|c|}
\hline \multirow[b]{2}{*}{ Identified compound } & \multicolumn{3}{|c|}{ Fatty acid (area $x 10^{5}$ ) } & \multirow[b]{2}{*}{ Identified compound } & \multicolumn{3}{|c|}{ Aromatic acid (area $\left.\times 10^{5}\right)$} \\
\hline & & $\begin{array}{l}25 \\
\mathrm{kDa}\end{array}$ & $50 \mathrm{kDa}$ & & $\begin{array}{l}3.5 \\
\mathrm{kDa}\end{array}$ & $\begin{array}{l}25 \\
\mathrm{kDa}\end{array}$ & $\begin{array}{l}50 \\
\mathrm{kDa}\end{array}$ \\
\hline Dodecanoic acid, methyl ester & 5.1 & 3.2 & 3.3 & Benzene, 1-methoxy-4-methyl- & 1.5 & 0.8 & 1.3 \\
\hline Tetradecanoic acid, methyl ester & 1.1 & 0.7 & 0.7 & Benzoic acid, methyl ester & 2.3 & & \\
\hline Tetradecanoic acid, methyl ester & 9.6 & 5.9 & 5.5 & Benzene, 1,2-dimethoxy- & 3.1 & & \\
\hline Tridecanoic acid, methyl ester & 5.0 & 3.5 & 3.1 & Benzene, 1,4-dimethoxy- & 0.6 & & \\
\hline $\begin{array}{l}\text { Tetradecanoic acid, 12-methyl-, } \\
\text { methyler }\end{array}$ & 1.7 & 1.1 & 1.0 & 1,2,3-Trimethoxybenzene & 0.5 & & \\
\hline Pentadecanoic acid, methyl ester & 3.3 & 1.7 & 1.5 & $\begin{array}{l}\text { Benzene, 4-ethenyl-1,2- } \\
\text { dimethoxy- }\end{array}$ & 0.6 & & \\
\hline Hexadecanoic acid, methyl ester & 0.8 & 0.6 & 0.5 & 1,2,4-Trimethoxybenzene & 0.5 & 1.5 & 1.6 \\
\hline $\begin{array}{l}\text { 9-hexadecenoic acid, methyl } \\
\text { ester, [Z]- }\end{array}$ & 2.0 & 1.3 & 1.1 & $\begin{array}{l}\text { Benzoic acid, 4-methoxy-, methyl } \\
\text { ester }\end{array}$ & 1.7 & 0.9 & 0.8 \\
\hline Hexadecanoic acid, methyl ester & 24.1 & 16.4 & 14.7 & $\begin{array}{l}\text { Benzoic acid, 3,4-dimethoxy-, } \\
\text { methyl ester }\end{array}$ & 1.1 & 0.6 & 6.2 \\
\hline $\begin{array}{l}\text { Heptadecanoic acid, methyl } \\
\text { ester }\end{array}$ & 1.0 & 0.8 & 0.7 & $\begin{array}{l}\text { Benzenesulfonamide, } \quad \mathrm{N} \text {-[3- } \\
\text { chloropropyl]-N }\end{array}$ & 4.1 & 14.6 & \\
\hline $\begin{array}{l}\text { Hexadecanoic acid, 14-methyl-, } \\
\text { methyl ester }\end{array}$ & 1.0 & 0.6 & 0.6 & Benzenesulfonamide, N-butyl- & 5.4 & 1.2 & 2.0 \\
\hline $\begin{array}{l}\text { 9-octadecenoic acid, methyl } \\
\text { ester }\end{array}$ & 1.0 & 0.7 & 0.6 & & & & \\
\hline $\begin{array}{l}\text { 9-octadecenoic acid[Z]-, methyl } \\
\text { ester }\end{array}$ & 1.4 & 1.1 & 0.9 & & & & \\
\hline Octadecanoic acid, methyl ester & 3.1 & 2.9 & 2.7 & & & & \\
\hline Total area & 60.0 & 40.6 & 37.0 & & 21.6 & 19.6 & 12.0 \\
\hline
\end{tabular}




\section{Figures}

Fig. 1. (a) Schematic diagram and procedure of COM isolation from CRNOM_

Fig. 2. Molecular weight distribution of various COM measured by HPSEC; (a) DOC response, (b)

UV detector, and (c) FL detector.

Fig. 3. Molecular weight distributions of diverse COMs measured by FIFFF technique: (a) DOC response, (b) UV, and (c) FL.

Fig. 4. FTIR spectra of COM isolated with and without HF dialysis procedure: (a) $3.5 \mathrm{kDa}$ COM, (b) 50 kDa COM. 
Figure 1

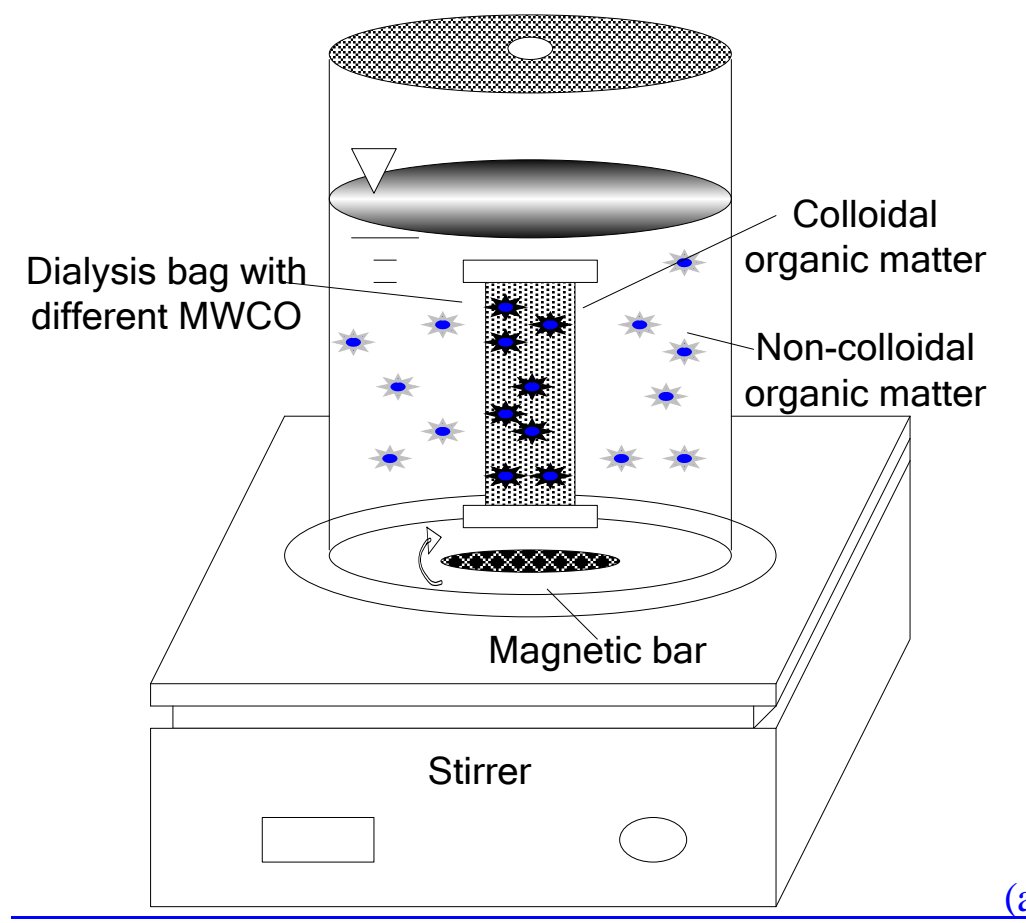

Spectra/P or regener ated cellulose dialysis membrane (with various MWCO)

I

Clean dialysis membrane for 1 day with pure water

J

Acidify sample (high concentration) about $\mathrm{pH} \sim 1$ with $\mathrm{HCl}$

II

Dialyze for each 8 hours in $0.1 \mathrm{~N}$ HC1 three times $\left(1\right.$ it, $\left.2^{\text {na }}, 3^{\text {il }} \mathrm{HC} 1\right)$

I

Dialyze until precipitates are removed in $0.2 \mathrm{~N} \mathrm{HF}$

I

Dialyze for 12 hours in pure water two times

(b) 


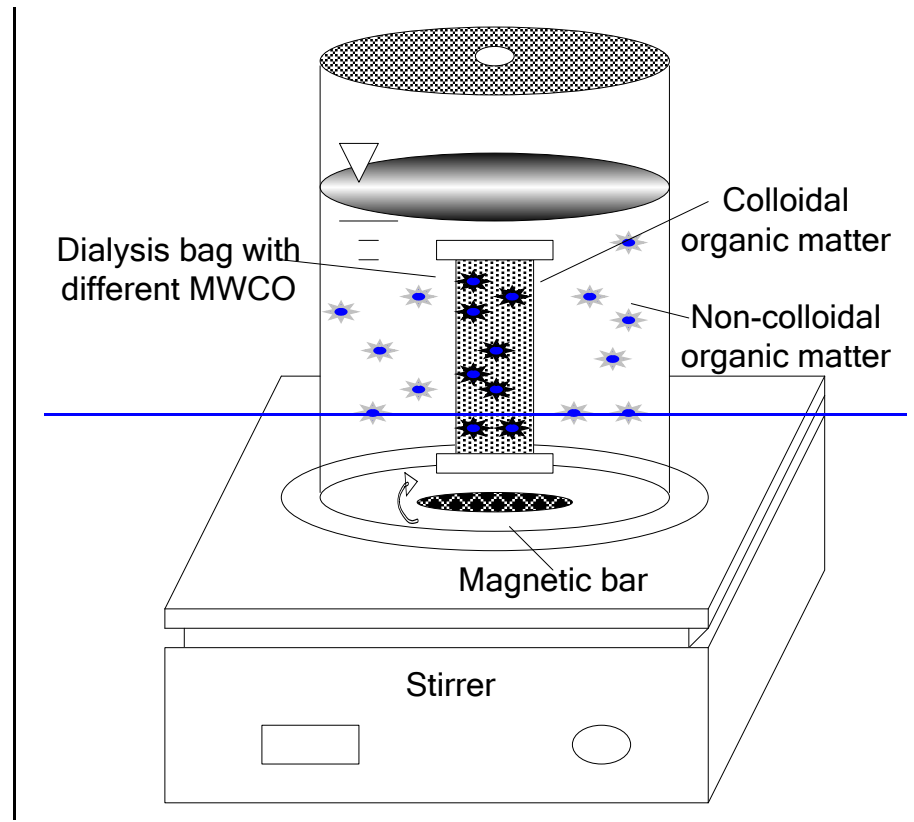


Figure 2

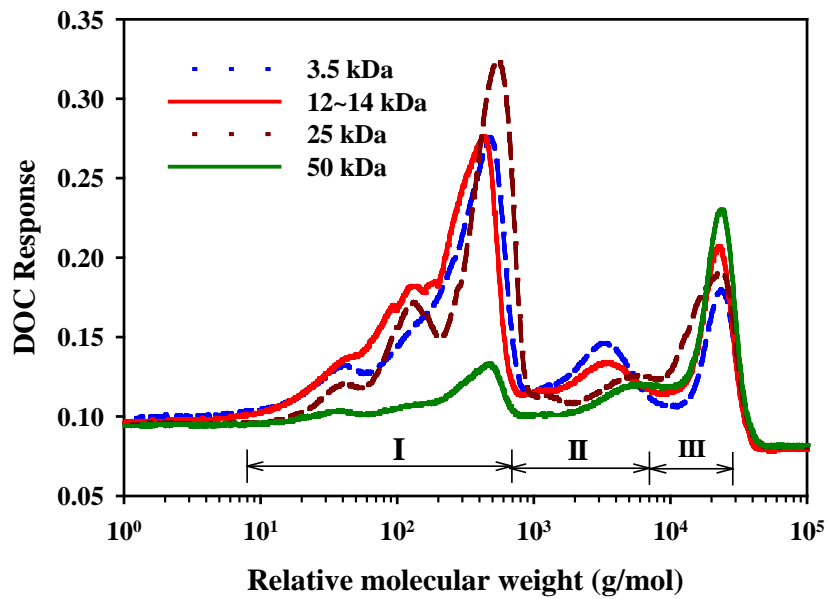

(a)

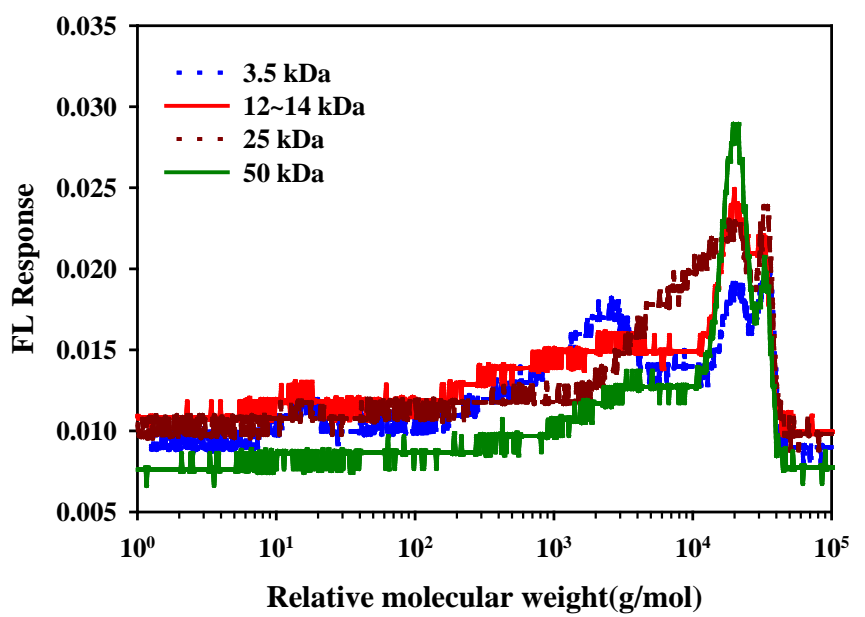

(c)

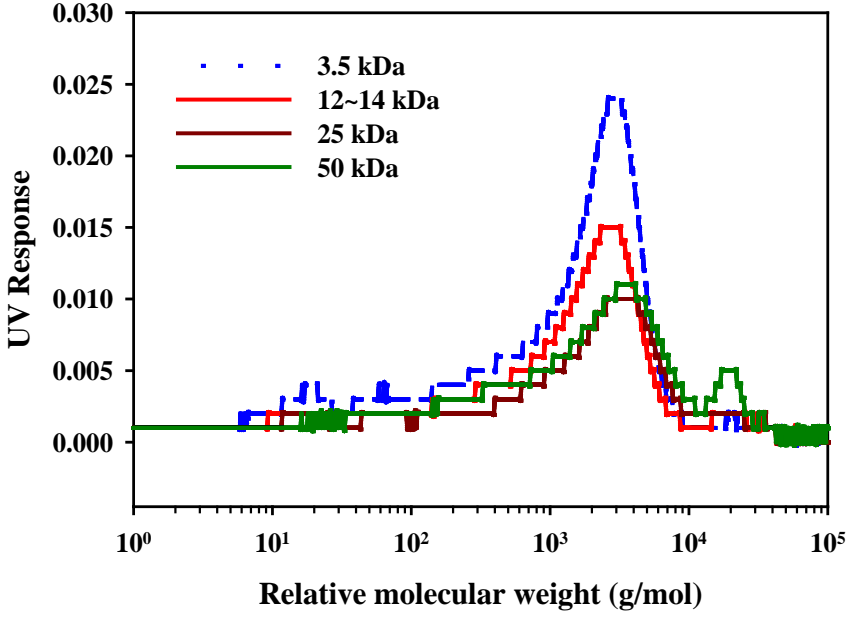

(b) 
Figure 3
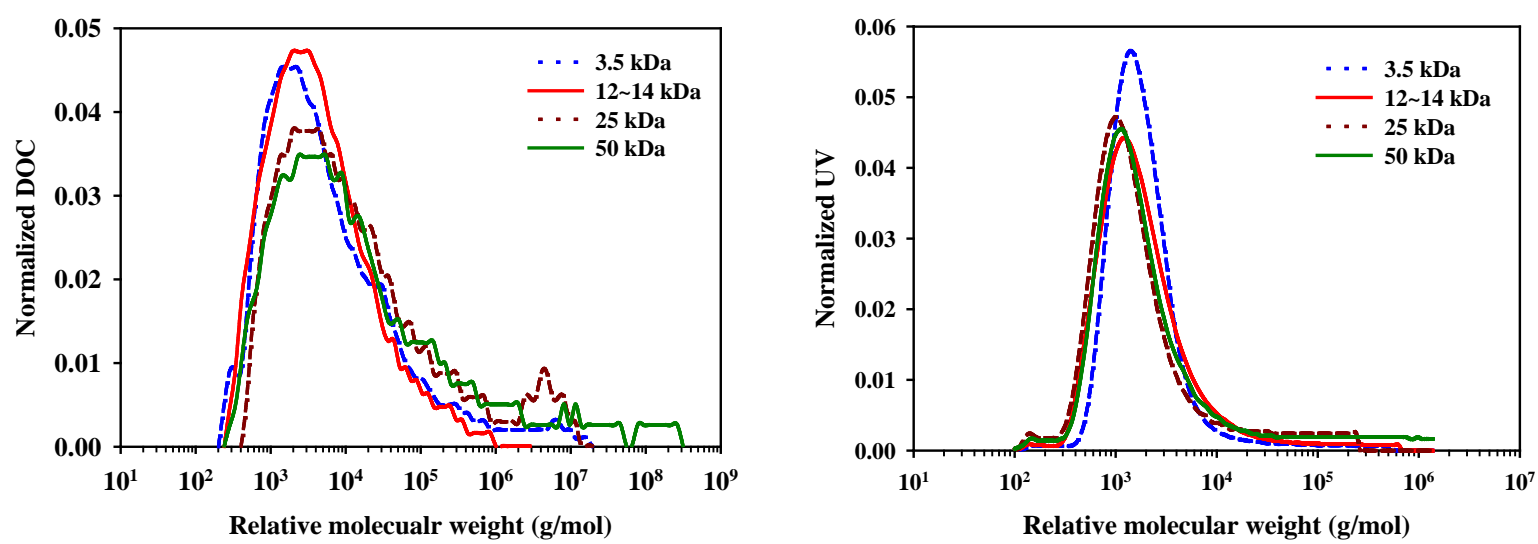

(a)

(b)

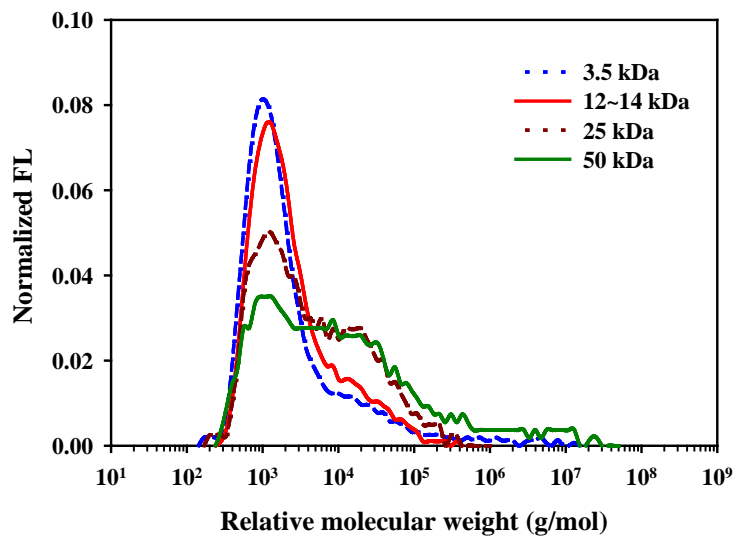

(c) 
Figure 4

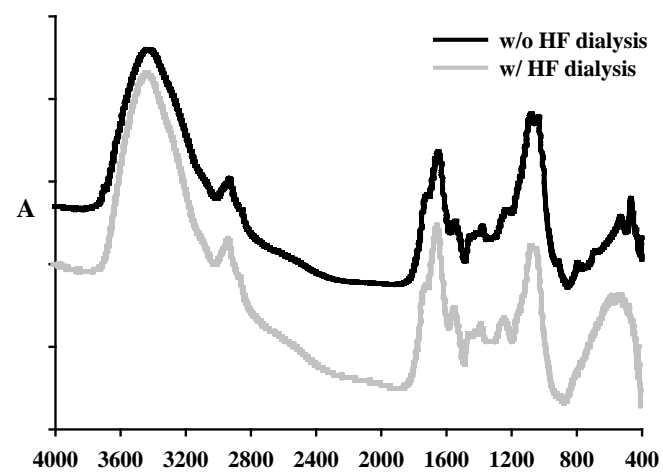

Wave number $(1 / \mathrm{cm})$

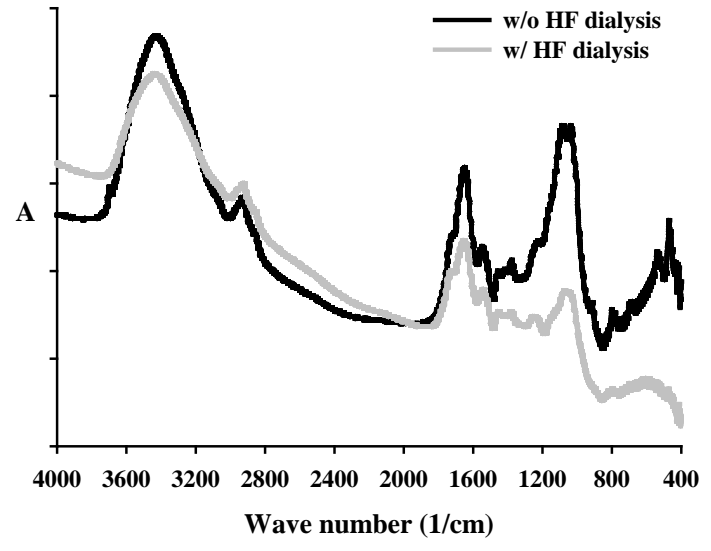

(b) 